\title{
HOME INDUSTRY INTIP MARKETING REACH OF SUMBERLAWANG DISTRICT VILLAGE, SRAGEN DISTRICT
}

\author{
Minda Rafiani ${ }^{1}$, MS Khabibur Rahman ${ }^{2}$, Muh. Husyain Rifa'i ${ }^{3}$ \\ 1,2,3 Geography Education Study Program, Veteran Bangun Nusantara \\ University \\ Email: Mindarafiani53@gmail.com
}

\begin{abstract}
The Marketing Range of Intip Home Industries at Jati Village Sumberlawang Sub-District Sragen Regency in 2018. Geography Education Program, Teacher Training and Education Faculty, Veteran Bangun Nusantara University, Sukohar. 2020.This study aims to determine the distribution of Intip Home Industry in Jati Village Sumberlawang Subdistrict Sragen Regency, to determine the effect of its marketing range on economic conditions and to know the labor's income of the Intip Home Industry in Sendangrejo Village Sumberlawang District, Sragen Regency. The method used in this study is Saturated Sampling Method which is the determination of the sample if all members of the population are used as samples. It is often done if the population is relatively small, less than 30 people, or the study wants to generalize with small errors. Another term of this method is a census, where all members of the population are sampled. Starting from this, the study included saturated samples because there were fewer than 30 people. The results of this study can be concluded that domestic marketing includes Pati, Jepara, Blora, Tuban, Mantingan, Jogja, Solo, Sragen, Boyolali, Wonogiri, Purwodadi, Demak, Kudus, Klaten, Delanggu, Ngawi, and Kartasura. The economic condition of the workforce in the home industry is relatively low, which is less than $R p$. 1,000,000 every month. The majority of dependents in worker's family is categorized as medium class with around 3-5 dependents for each family. The duration of their business is between 10-15 years.
\end{abstract}

Keywords: Home, Industry, Intip, Jati 


\section{A. INTRODUCTION}

Marketing is one of the main activities carried out by the company to maintain life sustainability and to develop the company to obtain profits from its corporate activities. The success or failure of a company in achieving its desired goals depends on the company's ability to carry out various functions in the company's fields, such as in the fields of marketing, finance, production and management as well as other fields that are regarded have influences to support achieving the company goals. According to Irawan (1998: 10), marketing is a social process where individuals and groups obtain what they need by creating and exchanging products and values with other individuals or groups.

Generally, marketing has been seen as the task of creating, introducing, and delivering goods to consumers both individual consumers and groups. The definition of marketing itself is a social and managerial process where the person or organization gets what they need through the creation and exchange of values with others (Kotler and Armstrong, 2008: 6). In marketing, the key to achieve organizational goals is companies must be more effective than competitors in creating, submitting and communicating customer values to selected target markets. Companies will succeed if they carefully select a number of targeted markets and prepare marketing programs designed according to customer needs for each of the targeted markets. If company has been able to work together to serve customer needs, it will produce a coordinated supplier, so that the company will gain benefits through customer satisfaction which is the ultimate goal of the company. Industry is a chain of processing raw materials into semi-finished goods or finished goods. According to the Law of the Republic of Indonesia Number 5 of 1984 about industry, states that industry is: "Economic activities that process raw materials, raw materials, semi-finished goods, and or goods to be an item with higher value, including industrial design and engineering activities ". Thus, 
industry is part of the production process, whose raw materials are taken directly (but not directly used by humans) or indirectly, and then the goods are processed until they become valuable goods for humans.

Intip is the rice crust with savory taste derived from the deposite crust of Nasi Liwet generating from the bottom of a pot that is cooked with firewood. One characteristic is the kinco (liquid Javanese sugar) sprinkle over fried or finely sprinkled salt to make salty taste. The making process of intip is complicated. The first step is to collect the rice crust that is embedded at the pan bottom which is produced if we traditionally cook the rice using kendil or a thick traditional pan made from alumunium or iron. This rice crust is then removed from the pan and dried under the sun to fry as the next step http://id.m.wikipedia.org/wiki. Intip industry has become one of the economic activities for people in Jati Village, Sumberlawang District, Sragen Regency Since 1995. Approximately, there are 5 owners of Intip industry in Sendangrejo Hamlet where the majority of people work on this industry. The growth of an industry is determined by the production factor support, as well as with Intip industry in Sendangrejo Hamlet, Sumberlawang District, Sragen Regency.

The results of this study aimed to determine the distribution and the range of Intip home industry and its influence to economic condition in Jati Village. All data is obtained from interview with workers, industry owners and related agencies through the field observation and documentation. The sample used on this study is $21 \%$ from the total population of labors. There are 5 Intip home industries in Jati village that has been well-known for its production and experience an increase sales compared to previous year. This progress certainly contributes to alleviate the economic condition of the industry workforce. The sale is not only marketed in the nearest area but also to other areas such as Yogyakarta, Demak, Kudus, Tuban, East Java. 
Sendangrejo Village is the founder in the development of Intip industry around the study area. One of the reasons to support this condition is the accessible raw materials and the high demand of market. Besides, the strategic location of this industry can ease buyers to buy the food. Each home industry has different number of workers but mostly come from surrounding area, also has different variations of taste for their productions.

The distance between home industries is relatively close to each other. The industry is concentrated in Sendangrejo Hamlet without any branches in the neighbour areas. The owner has its own strategy to attract consumers, such as by producing different variations for their products and by creating interesting package to draw customer's interest. This method succeeds to lure many customers and increase their sales income. Generally, each home industry has 0-10 workers in which there are 2 industries whose 6 workers, 2 industries whose 5 workers, and 1 industry whose 3 workers. It can be concluded that the industry of Sendangrejo Hamlet is categorized into small-scale home industry.

The distribution of Intip home industry can be differentiate from the number of products from each industry owner. The large scale product is indicated belong to Joni Hardiman that can produce 900 pieces of Intip each day, while the least production with 300 pieces belongs to Umi Latifa. This industry using direct marketing method in which consumers can immediately purchase the product using cash money or they can make an order to get the product, and usually the sellers will offer their products using private vehicle. The production of Intip industry in Sendangrejo Hamlet is usually marketed to Pati, Jepara, Blora, Tuban, Mantingan, Jogja, Solo, Sragen, Boyolali, Wonogiri, Purwodadi, Demak, Kudus, Klaten, Delanggu, Ngawi, Kartasura. 
The figure below shows the framework used in this study:

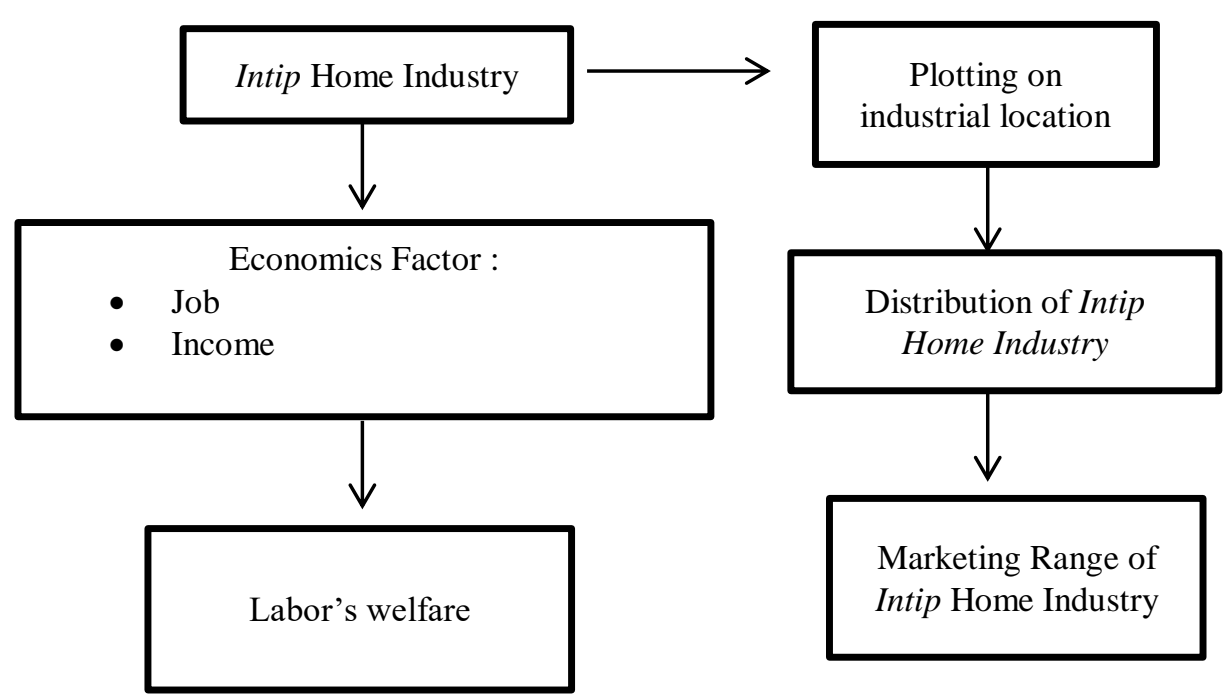

Figure 1. Research Framework

\section{B. RESEARCH METHOD}

This study used Saturated Sampling that can determine sample if all population sample is used. This is often done if the population is relatively small (less than 30 people), or the study has aim to make generalization with small errors. This method is also called cencus in which all population is used as sample. Therefore, this study used saturated sampling method since to population target is less than 30 people. This study used interview as data collection technique, and this method is used if fesearcher needs to conduct a preliminary study to find problems and to know depth information from interviewees, and if researchers needs to know the number of participants. This data collection technique is based on self-reports, or at least on personal knowledge and or beliefs. (Sugiyono, 2010: 137-138)

Interview was used to determine the distribution of Intip home industry, the marketing reach, and its influence on the economic conditions of Jati Village, Sumberlawang Sub District, Sragen Regency. The method used is 
descriptive method by describing or describing research subjects based on current facts and circumstances. Descriptive method is usually used to disclose a problem and to reveal the facts with some interpretations are given if needed. The results of this study are focused on providing an overview of the observed object (Tika in Sulistyowati Nugraheni 2015: 43). This descriptive method systematically describes the marketing range of home industry in Jati Village Sumberlawang Sub District, Sragen Regency.

\section{RESULTS AND DISCUSSION}

There are 5 Intip industries in Sendangrejo Hamlet and the products are marketed not only to the nearest area but also other cities. The location of this industry is close to each other so it makes consumers easier to choose or buy the food. The majority of Intip industries has 0-10 workers in which there are 2 industries whose 6 workers, 2 industries whose 5 workers, and 1 industry whose 3 workers. From this number then it can be concluded that Intip industry of Sendangrejo Hamlet is categorized into small-scale home industry. Table belos shows the number of labors for each industry :

Table 1. The number of labors in Intip industry

\begin{tabular}{llll}
\hline No & Owner & Labor & \\
\hline 1. & Joni Hardiman & 6 workers & \\
2. & Parmin & 6 workers & \\
3. & Waji & 5 workers & \\
4. & Kardi & 5 workers & \\
5 & Umi Latifa & 3 workers & \\
\hline & Total & & 25 \\
\hline
\end{tabular}

The largest production of Intip is produced by Joni Hardiman with 900 pieces each day while the least number belongs to Umi Latifa that produces 300 pieces per day. 
Table 2. The number of Intip production

\begin{tabular}{lll}
\hline No & Owner & Production (per day) \\
\hline 1. & Joni Hardiman & 900 pieces \\
2. & Parmin & 800 pieces \\
3. & Waji & 400 pieces \\
4. & Kardi & 500 pieces \\
5. & Umi latifa & 300 pieces \\
\hline
\end{tabular}

The distribution of Intip home industry in the study area includes the region of Pati, Jepara, Blora, Tuban, Mantingan, Jogja, Solo, Sragen, Boyolali, Wonogiri, Purwodadi, Demak, Kudus, Klaten, Delanggu, Ngawi, and Kartasura. The economic condition of the industry labor is categorized as low income which is less than Rp. 1000.000.000 each month. Based on the number of dependants, the majority of labors is classified as medium family with 3-5 dependants and the business has been last between 5-10 years.

\section{CONCLUSION AND RECOMMENDATION}

To conclude, there are 5 home industries that sell Intip product in Sendangrejo Hamlet whose market in surrounding and outside area. Looking from the number of labors, this industry has around 0-10 workers : 2 industries with 6 workers, 2 industries with 5 workers, and 1 industry with 3 workers. The highest production of this industry belongs to Joni Hardiman that produces 900 pieces of Intip each day while Umi Latifa positions the lowest number of production with only 300 pieces per day. The market of Intip industry reaches the region of Pati, Jepara, Blora, Tuban, Mantingan, Jogja, Solo, Sragen, Boyolali, Wonogiri, Purwodadi, Demak, Kudus, Klaten, Delanggu, Ngawi, and Kartasura.

By understanding the rapid development of informal sector, the government hopefully can be more concerned on the limitation of job vacancy problem, particularly to Intip home industry. It is better to provide gas stock to minimalize the problems on the process of Intip production. Also, it needs to increase the payment of labors to the amount of Regional 
Minimum Payment (UMR) of Sragen District regarding the increase of life expenses. It also needs to improve the rice quality on Intip making process to produce best quality product as well as improving the product packaging.

\section{E. REFERENCES}

Nugraheni, Sulistyowati. 2015. Karakteristik Dan Pola Persebaran Pedagang Hidangan Istimewa Kampung (HIK) Di Kecamatan Sukoharjo Kabupaten Sukoharjo Tahun 2015. Skripsi Pendidikan Geografi: Universitas Veteran Bangun Nusantara Sukoharjo.

Murti, Eri. 2009. Studi Industri Genteng Di Desa Demakan Kecamatan Mojolaban Kabupaten Sukoharjo Tahun 2007. Skripsi Pendidikan Geografi: Universitas Sebelas Maret Surakarta.

Ifadah, Muhimatun. 2014. Kehidupan Sosial Ekonomi Penduduk Pembuat Batu Bata Di Desa Rejosari Kecamatan Brangsong Kabupaten Kendal Tahun 2004-2013. Skripsi Fakultas Ilmu Sosial. Universitas Negeri Semarang.

Yumanda, Syahreza.2009.Strategi Pemasaran Keripik Singkong Industri Rumah Tangga Cap Kelinci Di Tanjung Morawa Kabupaten Deli Serdang Tahun 2009.Skripsi Fakultas Pertanian.Universitas Sumatera Utara.

Lestari, Tiara. 2016. Persebaran Industri Kerajinan Tatah Sungging Di Kelurahan Sonorejo Kecamatan Sukoharjo Kabupaten Sukoharjo Tahun 2016. Skripsi Pendidikan Geografi: Universitas Veteran Bangun Nusantara Sukoharjo.

Lestari, Titin. 2010. Kontribusi Industri Kecil Kerajinan Gitar Dalam Upaya Penyerapan Tenaga Kerja (Studi Kasus Pada Masyarakat Desa Ngrombo, Kecamatan Baki, Kabupaten Sukoharjo). Skripsi Fakultas Keguruan Dan Ilmu Pendidikan. Universitas Sebelas Maret Surakarta.

Permatasari, Sintia. 2017. Kondisi Sosial Ekonomi Masyarakat Pengrajin Gitar di Desa Mancasan Kecamatan Baki Kabupaten Sukoharjo Tahun 2017. Skripsi Pendidikan Geografi: Universitas Veteran Bangun Nusantara Sukoharjo.

https://id.m.wikipedia.org/wiki/Kerak_nasi(diaksespada pukul 10.56 WIB hari rabu 25 juli 2018 )

Tjiptono, Fandy. 2008. Strategi Pemasaran. Yogyakarta: CV. ANDI OFFSET.

Andi, 2005. Sistem Informasi Geografi Dengan Autocad Map. Wahana Komputer Semarang

Sugiyono. 2014. Metode Penelitian Kuantitatif Kualitatif Dan R\&D. Bandung: Alfabeta.

Setyowati., Dkk., 2014 . Kartografi Dasar. Ombak 
Banowati, Eva . 2014. Geografi Indonesia . Ombak

Moleong, Lexy . 2014.Metode Penelitian Kuantitatif Kualitatif.Bandung : PT Remaja Rosdakarya

Adi wijaya, Arik. 2013. Analisis Strategi Pemasaran Makanan Tradisional (Studi Kasus pada Home industry Rengginang Halimatus Sa'diyah Kalibaru Di Kabupaten Banyuwangi). Skripsi Fakultas Ekonomi: Universitas Jember

Tim Penyusun. 2015. Pedoman Penyusunan Tugas Akhir Skripsi Dan Tesis. Sukoharjo: Veteran Bangun Nusantara University Press. 